\title{
Milk production responses, rumen fermentation, and blood metabolites of dairy cows fed increasing concentrations of forage rape (Brassica napus ssp. biennis)
}

\author{
J. P. Keim, ${ }^{1 *} \odot$ J. Daza, ${ }^{1} \dagger \odot$ I. Beltrán, ${ }^{2} \odot$ O. A. Balocchi, ${ }^{1} \oplus$ R. G. Pulido, ${ }^{3} \odot$ P. Sepúlveda-Varas, ${ }^{3} \odot$ \\ D. Pacheco, ${ }^{4} \odot$ and R. Berthiaume ${ }^{5}$ \\ ${ }^{1}$ Faculty of Agricultural Sciences, Universidad Austral de Chile, Independencia 641, Valdivia 5110566, Chile \\ ${ }^{2}$ Instituto de Investigaciones Agropecuarias, INIA Remehue, Casilla 24-O, Osorno 5290000, Chile \\ ${ }^{3}$ Faculty of Veterinary Sciences, Universidad Austral de Chile, Independencia 641, Valdivia 5110566, Chile \\ ${ }^{4}$ Animal Science Group, Grasslands Research Centre, Private Bag 11008, Palmerston North 4442, New Zealand \\ ${ }^{5}$ Valacta, Dairy Centre of Expertise, 555 Blvd des Anciens-Combattants, Ste-Anne-de-Bellevue, QC H9X 3R4, Canada
}

\begin{abstract}
The aim of this study was to determine animal performance, rumen fermentation, and health-related blood metabolites of dairy cows in mid lactation fed with increasing levels (30 and 45\%) of forage rape (FR) in the diet. Twelve pregnant multiparous lactating Holstein-Friesian dairy cows were randomly allocated to 1 of 3 dietary treatments in a replicated $3 \times 3$ Latin square design. The experiment was divided into three 21-d periods. For the control diet, $13.0 \mathrm{~kg}$ (dry matter, DM) of grass silage, $3.0 \mathrm{~kg}$ DM of commercial concentrate, $2.7 \mathrm{~kg}$ of DM cold-pressed extracted canola meal, and $0.45 \mathrm{~kg} \mathrm{DM}$ of solvent-extracted soybean meal were offered daily. For the other two treatments, 30 and $45 \%$ of the DM from silage, canola meal, and commercial concentrate were replaced in equal proportions with FR. Data were analyzed individually using linear and quadratic orthogonal polynomials. Ingestive behavior was altered by the inclusion of FR. We observed a linear increase in eating time at the expense of rumination time. Nevertheless, total DM intake was not affected by dietary treatments, averaging $19.5 \pm$ $0.24 \mathrm{~kg}$ of $\mathrm{DM} / \mathrm{d}$. Milk yield increased linearly with increasing concentration of FR in the diet. Thus, feed efficiency of cows ( $\mathrm{kg}$ of milk $/ \mathrm{kg}$ of DM intake) increased linearly with the percentage of FR in the diet. Inclusion of FR in the diet had no effect on milk composition or milk sensory characteristics. Mean rumen $\mathrm{pH}$ of cows decreased linearly from the control to the $45 \% \mathrm{FR}$ diet; however, dietary treatments had no effect on the daily amount of time that rumen $\mathrm{pH}$ was below 5.8 (252 \pm
\end{abstract}

Received April 24, 2020

Accepted June 1, 2020.

*Corresponding author: juan.keim@uach.cl

$\dagger$ Current address: Instituto de Investigaciones Agropecuarias, INIA Tamel Aike, Las Lengas 1450, Coyhaique 5950228, Chile.
71.4), indicating no risk of subacute ruminal acidosis. Concentrations of total volatile fatty acids in the rumen and molar proportions of acetate and butyrate were increased with FR inclusion, whereas the proportion of propionate was linearly reduced. Excretion of uric acid and total purine derivatives tended to be greater for cows fed FR, which resulted in a trend toward a linear increase in estimated microbial $\mathrm{N}$ flow. However, $\mathrm{N}$ use efficiency was not affected by FR inclusion. Although differences for some hematological measures (increased white blood cell and neutrophils counts) and a quadratic response for glutamate dehydrogenase for cows fed FR in the diet (decreased with inclusion of $30 \%$ and increased with $45 \%$ in the diet) were observed, all values were within appropriate ranges for dairy cows. These results indicated that including FR to dairy cow diets, up to $45 \%$ of diet DM, improved milk production due to changes in volatile fatty acids and predicted microbial $\mathrm{N}$ flow and had no negative effects on dairy cow health or sensory characteristics of milk.

Key words: Brassica, volatile fatty acids, purine derivatives, health

\section{INTRODUCTION}

Forage rape (FR; Brassica napus ssp. biennis) is a crop used in grazing systems to supply supplementary feed in times of low pasture growth because it (1) can produce high yields of DM (8-15 t of DM/ha) in a relatively short period (60-120 d; Barry, 2013); (2) has low establishment costs; (3) uses water and nitrogen efficiently; and (4) has high concentrations of digestible DM and CP (Kaur et al., 2011). This crop can be incorporated in an annual crop rotation to improve feeding budgets in pasture-based systems (Garcia et al., 2008). In terms of nutrient concentration, FR is highly digestible (75-85\% digestible $\mathrm{OM})$, contains between 10 and $20 \% \mathrm{CP}$, has low NDF (18-20\%) and high con- 
centrations of readily fermentable carbohydrates such as starch (6-11\%), sugars (10-15\%), and pectins (9\%), and therefore ferments rapidly in the rumen (Sun et al., 2012; Westwood and Mulcock, 2012; Keim et al., 2019).

Inclusion of FR in the diet can improve animal feed conversion efficiency compared with legumes (Kaur et al., 2010) or silage plus concentrate diets (CastilloUmaña et al., 2020). This reduces feeding costs and increases farm profitability because homegrown forages are frequently less expensive than purchased concentrates (Garcia et al., 2008). Moreover, FR has been shown to reduce the environmental impact of sheep grazing pasture diets (Sun et al., 2012) and dairy cows fed alfalfa hay or chicory (Williams et al., 2016) through lower $\mathrm{CH}_{4}$ production either per day or per kilogram of ECM.

However, FR and other brassica forages contain secondary compounds [e.g., S-methyl-cysteine sulfoxide (SMCO), glucosinolates, and nitrates] in greater concentrations than other forages that can cause nutritional disorders and subclinical alterations that are implicated in reduced voluntary intake and underperformance, affect rumen fermentation, and alter sensory characteristics of milk (Barry, 2013). Other characteristics of FR, such as high moisture concentration, inadequate fiber concentration, and altered rumen fermentation, may also contribute to negative effects on animal performance or health when these crops are fed (Lambert et al., 1987). Cattle allocated high rates (ad libitum) of FR and preferentially consuming FR leaves may be at greater risk of SARA, because of the low NDF content and high concentrations of readily fermentable carbohydrates (Westwood and Mulcock, 2012).

Thus, it has been recommended that brassicas can be provided as a minor proportion $(0.2-0.3)$ of dairy cow diets to dilute secondary compounds (Westwood and Mulcock, 2012; Barry, 2013). Castillo-Umaña et al. (2020) observed that although DMI was reduced with inclusion of $25 \% \mathrm{FR}$ in the diet, milk production was not affected. Conversely, Williams et al. (2016) reported no decrease in DMI and greater milk production with dairy cows fed $43 \% \mathrm{FR}$ in an alfalfa hay-based diet. However, health condition and milk characteristics were not reported in their study.

The aim of this study was to determine DMI, rumen fermentation, health-related blood metabolites, milk sensory characteristics, and production responses of mid-lactation dairy cows fed increasing concentrations (30 and $45 \%$ ) of FR in the diet. We hypothesize that FR can be included in the diet of mid-lactation dairy cows without negatively affecting DMI, rumen fermentation, health-related blood metabolites, milk sensory characteristics, or production responses.

\section{MATERIALS AND METHODS}

The study was conducted at the Experimental Research Station of Universidad Austral de Chile, Valdivia, Chile, between January and March 2018. All experimental procedures were approved by the Universidad Austral Institutional Animal Care and Use Committee (Approval Number: 237/2015).

\section{Animals, Housing, and Experimental Design}

Twelve pregnant multiparous lactating HolsteinFriesian dairy cows $(24.1 \pm 0.72 \mathrm{~kg}$ of milk/d, $540 \pm$ $7.3 \mathrm{~kg}$ of BW, and $142 \pm 3.9$ DIM at the start of the study; $\pm \mathrm{SD}$ ) were used in this study. All animals were housed in the same tiestall barn, equipped with stalls with rubber bedding. Animals were milked twice daily at 0700 and $1600 \mathrm{~h}$ in the milking parlor close to the barn facility and had ad libitum access to water.

Cows were randomly allocated to 1 of 3 dietary treatments in a replicated $3 \times 3$ Latin square design. The experiment lasted $63 \mathrm{~d}$ and was divided into three $21-\mathrm{d}$ periods. The first $14 \mathrm{~d}$ of each period was for adaptation of the animals to the diets, and the last $7 \mathrm{~d}$ was used for data collection. Seven days before the first experimental period, cows were housed for adaptation to the experimental conditions and offered the control diet, which was composed of $13.0 \mathrm{~kg}$ DM of grass silage, $3.0 \mathrm{~kg} \mathrm{DM}$ of commercial concentrate, $2.7 \mathrm{~kg} \mathrm{DM}$ of cold-pressed extracted canola meal, and $0.45 \mathrm{~kg}$ DM of soybean meal (Table 1). The amount offered daily was increased proportionally for each feed ingredient to achieve $\sim 5 \%$ orts.

\section{Brassica Crop Production and Animal Feeding}

The 'Spitfire' cultivar of FR was sown in October and November 2017 in 2 adjacent 0.5-ha areas at a density of $4 \mathrm{~kg}$ of seed/ha. The crop was sown on 2 dates at a 20-d interval so that we could offer plant material at a similar stage of maturity throughout the experiment. Daily, FR was harvested with a cutter bar mower (Bertolini 140L, Reggio Emilia, Italy) at $10 \mathrm{~cm}$ above ground level and transported to the animals.

Cows were divided into 3 dietary treatments: (1) control, (2) 30\% FR, and (3) 45\% FR (Table 1). The control diet was composed of $67 \%$ grass silage, $15.5 \%$ commercial concentrate, $2.3 \%$ soybean meal, $13.9 \%$ canola meal, and $1.3 \%$ mineral salts of total DM offered. For the other 2 dietary treatments, 30 and $45 \%$ of the DM from silage ( 46.2 and $35.7 \%$ of total DM offered for $30 \% \mathrm{FR}$ and $45 \% \mathrm{FR}$ ), commercial concentrate (10.7 and $8.2 \%$ of total DM offered for $30 \%$ FR and $45 \% \mathrm{FR}$ ), and cold-pressed extracted canola meal 
Table 1. Ingredient and chemical composition of the experimental diets (\% of DM basis unless stated)

\begin{tabular}{|c|c|c|c|}
\hline \multirow[b]{2}{*}{ Item } & \multicolumn{3}{|c|}{$\operatorname{Diet}^{1}$} \\
\hline & Control & $30 \% \mathrm{FR}$ & $45 \% \mathrm{FR}$ \\
\hline \multicolumn{4}{|l|}{ Ingredient } \\
\hline Grass silage $^{2}$ & 67.0 & 46.2 & 35.7 \\
\hline Commercial concentrate ${ }^{3}$ & 15.5 & 10.7 & 8.2 \\
\hline Soybean meal ${ }^{4}$ & 2.3 & 2.3 & 2.3 \\
\hline Canola meal $l^{5}$ & 13.9 & 9.6 & 7.4 \\
\hline Forage rape $^{6}$ & 0 & 30.0 & 45.0 \\
\hline Mineral and vitamin supplement & 1.3 & 1.3 & 1.3 \\
\hline \multicolumn{4}{|l|}{ Chemical composition } \\
\hline DM & 56.6 & 42.5 & 36.4 \\
\hline Ash & 6.9 & 9.0 & 10.1 \\
\hline aNDFom $^{7}$ & 38.7 & 32.4 & 29.2 \\
\hline $\mathrm{ADFom}^{7}$ & 24.2 & 20.8 & 19.1 \\
\hline $\mathrm{CP}$ & 17.0 & 17.4 & 17.6 \\
\hline Lipid & 4.9 & 4.3 & 3.9 \\
\hline $\mathrm{NFC}^{8}$ & 29.1 & 33.6 & 35.7 \\
\hline Digestible OM & 74.4 & 75.5 & 75.9 \\
\hline $\mathrm{NE}_{\mathrm{L}}(\mathrm{Mcal} / \mathrm{kg} \mathrm{DM})$ & 1.71 & 1.73 & 1.74 \\
\hline \multicolumn{4}{|c|}{${ }^{1} 30 \% \mathrm{FR}=70 \%$ control diet and $30 \%$ forage rape $45 \% \mathrm{FR}=55 \%$ control diet and $45 \%$ forage rape. } \\
\hline \multicolumn{4}{|c|}{$\begin{array}{l}{ }^{2} \text { Grass silage composition: } 41 \% \mathrm{DM}, 8 \% \text { ash, } 48.8 \% \mathrm{NDF}, 12.4 \% \mathrm{CP}, 3.2 \% \text { lipids, } 72 \% \mathrm{dOM} \text { (OM degraded, as } \\
\text { a } \% \text { of original } \mathrm{OM} \text { ), } \mathrm{NE}_{\mathrm{L}}: 1.65 \mathrm{Mcal} / \mathrm{kg} \text { of DM. }\end{array}$} \\
\hline \multicolumn{4}{|c|}{$\begin{array}{l}{ }^{3} \text { Commercial concentrate composition: } 87 \% \mathrm{DM}, 3.4 \% \text { ash, } 22.8 \% \mathrm{NDF}, 17.3 \% \mathrm{CP}, 6.1 \% \text { lipids, } 87 \% \mathrm{dOM} \text {, } \\
\mathrm{NE}_{\mathrm{L}}: 1.99 \mathrm{Mcal} / \mathrm{kg} \text { of DM. }\end{array}$} \\
\hline \multicolumn{4}{|c|}{$\begin{array}{l}{ }^{4} \text { Soybean meal composition: } 88 \% \mathrm{DM}, 7.4 \% \text { ash, } 7.8 \% \mathrm{NDF}, 52.3 \% \mathrm{CP}, 1.2 \% \text { lipids, } 91 \% \text { dOM, NE } \mathrm{L}_{\mathrm{L}}: 2.09 \\
\text { Mcal/kg of DM. }\end{array}$} \\
\hline \multicolumn{4}{|c|}{$\begin{array}{l}{ }^{5} \text { Canola meal composition: } 90 \% \mathrm{DM}, 6.1 \% \text { ash, } 21.5 \% \mathrm{NDF}, 34.2 \% \mathrm{CP}, 12.9 \% \text { lipids, } 78 \% \text { dOM, } \mathrm{NE}_{\mathrm{L}}: 1.79 \\
\mathrm{Mcal} / \mathrm{kg} \text { of DM. }\end{array}$} \\
\hline \multirow{2}{*}{\multicolumn{4}{|c|}{$\begin{array}{l}{ }^{6} \text { Forage rape composition: } 11.5 \% \mathrm{DM}, 14.1 \% \text { ash, } 18.8 \% \mathrm{NDF}, 19.9 \% \mathrm{CP}, 2.9 \% \text { lipids, } 78 \% \mathrm{dOM}, \mathrm{NE}_{\mathrm{L}}: 1.79 \\
\text { Mcal/kg of DM. } \\
{ }^{7} \text { aNDFom = NDF in the OM; ADFom = ADF in OM, determined by sequential fiber analysis with correction } \\
\text { for residual ash (Cassida et al., 2007). }\end{array}$}} \\
\hline & & & \\
\hline \multicolumn{4}{|c|}{${ }^{8}$ Calculated according to NRC (2001): NFC $=100-(\% \mathrm{NDF}+\% \mathrm{CP}+\%$ fat $+\%$ ash $)$} \\
\hline
\end{tabular}

(9.6 and $7.4 \%$ of total DM offered for $30 \% \mathrm{FR}$ and $45 \%$ FR) were replaced with FR $(46.3 \pm 3.2 \%$ leaf, $23.0 \pm 1.9 \%$ petioles, and $30.7 \pm 4.9 \%$ stems $)$. The amount of soybean meal remained constant to keep the 3 diets isoenergetic and isonitrogenous, which met the $\mathrm{NE}_{\mathrm{L}}$ and MP requirements of the cows based on NRC (2001) recommendations.

Before feeding, all feeds were weighed and offered individually to each cow according to the dietary treatments. Grass silage and canola meal were offered twice a day at 0800 and $1700 \mathrm{~h}$ and soybean meal was offered once a day at $1700 \mathrm{~h}$ along with mineral salts. Once cows consumed the canola and soybean meal, grass silage was offered. For FR treatments, orts of grass silage were removed at 1100 and $1900 \mathrm{~h}$, and a fresh portion of FR was offered at the same allowance for a.m. and p.m. feeding. Commercial concentrate was offered twice daily during milkings (0700 and $1600 \mathrm{~h}$ ).

\section{Intake and Ingestive Behavior}

The amount of feeds offered and orts were weighed for each cow and recorded on d 1, 3, and 5 of wk 3 of each period. Subsamples of each feed ingredient and orts were collected and DM content was determined by weighing before and after drying in a forced-air oven at $105^{\circ} \mathrm{C}$ for $12 \mathrm{~h}$ and then stored for further nutrient concentration analysis. Nutrient intake of each feed ingredient was calculated as the difference between the amount offered multiplied by its nutrient concentration, and the dry weight of orts multiplied by its nutrient concentration. In case of FR and grass silage, there were always some orts, whereas supplements were completely consumed. Samples of forages (grass silage and FR) were freeze-dried and ground through a 1-mm screen (Wiley mill, Arthur H. Thomas, Philadelphia, PA) before chemical analyses. Leaves + petioles and stems of FR were analyzed separately. Samples for chemical analyses of commercial concentrate, soybean meal, and canola meal were taken once per experimental period. For each sample, ash and lipids were analyzed according to AOAC International (1996; method 942.05 and 920.39 for ash and ether extract, respectively); N content was determined by combustion (model FP-428 Nitrogen Determinator, Leco Corp., St Joseph, MI) and was used to calculate $\mathrm{CP}(\mathrm{N} \times 6.25)$. Neutral 
detergent fiber was determined as NDF in the OM (aNDFom; Van Soest et al., 1991) using sodium sulfite (Merck, Darmstadt, Germany) and heat-stable amylase (Ankom Technology Corp., Macedon, NY), and ADF in the $\mathrm{OM}(\mathrm{ADF}$ ) $)$ according to AOAC International (1996; method 973.18). Sequential fiber analysis with correction for residual ash was conducted, as pectins and ash can interfere with detergent fiber analysis of brassica forages (Cassida et al., 2007); OM degraded as a percent of original DM was measured according to Tilley and Terry (1963), and $\mathrm{NE}_{\mathrm{L}}$ was estimated according to NRC (2001).

Behavior was evaluated based on the following activities: eating (bite procurement, chewing between bites, or searching), rumination (standing or lying behavior of the animal), and other activities (resting, social interactions, drinking, demonstration of estrus, and others). Each activity was visually and continuously recorded by trained operators on d 4 of each experimental week, with each operator working in sequences of $6 \mathrm{~h}$. Every $10 \mathrm{~min}$, from 0800 to $1600 \mathrm{~h}$ and from 1700 to 0700 $\mathrm{h}$ (presence of the cows in the barn), operators noted the activity that each cow was performing. Each activity's time was calculated by summation of all 10-min intervals of activity.

\section{Production, Composition, and Sensory Characteristics of Milk}

Cows were milked at 0700 and $1600 \mathrm{~h}$ and milk yield was recorded daily with a flow sensor (MPC580 DeLaval, Tumba, Sweden) during the experimental periods. The daily average for the final week of each period is reported. Representative milk samples were collected with Waikato MK V lactometers (Waikato, New Zealand) at the morning and afternoon milkings for $3 \mathrm{~d}$ in the last week of the experimental period to determine fat, protein, lactose, and MUN analyses by mid-infrared spectrophotometry (Foss 4300 MilkoScan, Foss Electric, Hillerød, Denmark).

For descriptive sensory analysis, milk samples of cows under the same treatment were pooled within a period. Milk samples were pasteurized $\left(65^{\circ} \mathrm{C}\right.$ for 25 min) and presented to the sensory panel at $20^{\circ} \mathrm{C}$. The panel was composed of 10 trained judges who were not provided any information about the previous treatment of the milk samples. The judges were given $25 \mathrm{~mL}$ of milk in coded plastic glasses and evaluated the following attributes: milk odor, general flavor, spiciness, and bitterness. The judges evaluated the milk samples sequentially by rating the attributes on a continuous intensity scale from 1 to 9 , where 1 represents a highly inadequate attribute and 9 highly adequate (Seguel et al., 2020). Scores from each judge were considered an analytical replicate, and the average value for pooled milk samples within an experimental period was considered the experimental unit.

\section{Rumen Fermentation}

Rumen fluid was harvested by stomach tubing (Flora Rumen Scoop; Prof-Products, Guelph, ON, Canada) after each milking at 0800 and $1700 \mathrm{~h}$ on $\mathrm{d} 6$ of wk 3 in each experimental period. Samples were strained through 4 layers of cheesecloth. A 10-mL sample was drawn off, mixed with $0.2 \mathrm{~mL}$ of $50 \%$ (wt/vol) sulfuric acid, and stored at $-20^{\circ} \mathrm{C}$ pending determination of VFA and $\mathrm{NH}_{3}$ concentrations. Rumen fluid was allowed to thaw for $16 \mathrm{~h}$ at $4^{\circ} \mathrm{C}$ and then centrifuged at 10,000 $\times g$ for 10 min at $4^{\circ} \mathrm{C}$. Six milliliters of supernatant was drawn off and centrifuged at 10,000 $\times g$ for $10 \mathrm{~min}$ at $4^{\circ} \mathrm{C}$. Thawed supernatant of rumen fluid samples was analyzed for VFA by GC as described by Tavendale et al. (2005) and for $\mathrm{NH}_{3}$ by the phenol-hypochlorite reaction method (Weatherburn, 1967). Minor VFA are the sum of isobutyrate, isovalerate, valerate and caproate.

For the whole experiment, rumen $\mathrm{pH}$ was monitored by wireless telemetric $\mathrm{pH}$ bolus (eCow, Exeter, UK). The $\mathrm{pH}$ boluses were calibrated before use, programmed to measure rumen $\mathrm{pH}$ at 15-min intervals, and inserted directly into the ventral sac of the rumen of each cow. The data were transmitted wirelessly to a transceiver connected to a cellphone and then transferred to a laptop computer. The $\mathrm{pH}$ data were summarized as mean $\mathrm{pH}, \mathrm{pH}$ per hour, and time spent at $\mathrm{pH}>6.2,5.8 \leq \mathrm{pH}$ $\geq 6.2$, and $\mathrm{pH}<5.8$.

\section{Urine Collection and Purine Derivative Measurements}

To predict rumen microbial N (MN) flow based on purine derivatives (PD), spot urine samples $(20 \mathrm{~mL})$ were collected by subvulvar stimulation every $3 \mathrm{~h}$ during d 5 of wk 3 in each experimental period. Samples were acidified with $2 \mathrm{~mL}$ of $\mathrm{H}_{2} \mathrm{SO}_{4}(10 \% \mathrm{vol} / \mathrm{vol})$ to maintain $\mathrm{pH}$ below 3 and stored at $-20^{\circ} \mathrm{C}$. Urine samples were thawed and a composite sample per cow was made for each period and analyzed for allantoin, uric acid, and creatinine by HPLC. The equations used in calculating the predicted MN outlined below have been described previously (Totty et al., 2013).

The PD index was calculated based on total PD [allantoin $(\mathrm{mmol} / \mathrm{L})+\operatorname{uric}$ acid $(\mathrm{mmol} / \mathrm{L})]$ :

$$
\begin{gathered}
\mathrm{PD} \text { index }=\{[\text { total } \mathrm{PD}(\mathrm{mmol} / \mathrm{L})] / \\
\text { creatinine }(\mathrm{mmol} / \mathrm{L})\} \times \mathrm{BW}^{0.75},
\end{gathered}
$$


where $\mathrm{BW}^{0.75}$ is metabolic BW.

Urine volume was estimated using creatinine concentration as a marker and assuming a daily creatinine excretion of $26 \mathrm{mg} / \mathrm{kg}$ of BW (Lindberg, 1989). The estimated urinary creatinine excretion $(0.9 \mathrm{mmol} / \mathrm{kg}$ of $\mathrm{BW}^{0.75}$ ) was included in the following equation to estimate the daily excretion of PD $\left(\mathrm{mmol} / \mathrm{kg}\right.$ of $\left.\mathrm{BW}^{0.75}\right)$ :

daily excretion of $\mathrm{PD}\left(\mathrm{dPD} ; \mathrm{mmol} / \mathrm{kg}\right.$ of $\left.\mathrm{BW}^{0.75}\right)=$

$$
\mathrm{PD} \text { index } \times 0.9 \text {. }
$$

From this, the amount of purines absorbed daily was estimated:

$$
\begin{gathered}
\text { daily absorbed purines }(\mathrm{daP})= \\
{\left[\mathrm{dPD}\left(\mathrm{mmol} / \mathrm{kg} \text { of } \mathrm{BW}^{0.75}\right)-0.385 \times \mathrm{BW}^{0.75}\right]+0.85 .}
\end{gathered}
$$

Finally, MN (g/d) was estimated using the following equation:

$$
\operatorname{MN}(\mathrm{g} / \mathrm{d})=(\mathrm{daP} \times 70) /(0.116 \times 0.83 \times 1,000) .
$$

\section{Hematological and Biochemical Blood Measures}

Blood samples were collected after morning milking on d 4 of wk 3 in each period. Blood was collected from a coccygeal vessel using 2 evacuated blood collection tubes (BD Vacutainer; Becton, Dickinson and Company, Franklin Lakes, NJ): 1 containing EDTA (4 $\mathrm{mL})$ and 1 with no anticoagulant $(9 \mathrm{~mL})$. Samples were transported on ice to the hematology laboratory of the Universidad Austral de Chile Teaching Hospital for analysis, where they were centrifuged at $3,000 \times g$ for $10 \mathrm{~min}$ at $25^{\circ} \mathrm{C}$. Whole blood was used for determination of red blood cell (RBC) counts, hemoglobin $(\mathbf{H b})$ concentration, hematocrit (PCV), mean corpuscular volume (MCV), mean corpuscular $\mathrm{Hb}(\mathbf{M C H})$, mean corpuscular $\mathrm{Hb}$ concentration (MCHC), white blood cell (WBC) counts, and differential leucocytic count, using an automated hematology analyzer (KX-21N, Sysmex, Kobe, Japan) was used. Heinz bodies were counted in blood smears prepared on average $5 \mathrm{~h}$ after sampling, using crystal violet staining, and expressed as percent erythrocytes containing one or more inclusion bodies. Serum samples were stored at $-20^{\circ} \mathrm{C}$ until analyzed for BUN, $\gamma$-glutamyl transferase (GGT), glutamate dehydrogenase (GLDH), nonesterified fatty acids (NEFA), BHB, and aspartate aminotransferase (AST), using a Wiener Metrolab 2300 auto-analyzer (Wiener Lab, Rosario, Argentina) at $37^{\circ} \mathrm{C}$. Thyroxine $\left(\mathbf{T}_{4}\right)$ and triiodothyronine $\left(\mathbf{T}_{3}\right)$ were measured using a validated Elisa Kit (MyBioSource, San Diego, CA).

\section{Statistical Analyses}

Data were analyzed using the mixed model procedure of SAS (SAS Institute Inc., Cary, NC) to account for carryover effects according to the following model:

$$
y_{i j k l m}=\mu+S_{i}+A_{(i) j}+P_{(i) k}+T_{l}+C_{m}+e_{(i j k) l},
$$

where $y_{i j k l m}$ is an observation for each dependent variables; $\mu$ is the general mean; $S_{i}$ is the fixed effect of the $i$ th treatment sequence $(i=1$ to 6$) ; A_{(i) j}$ is the random effect of the $j$ th cow in the $i$ th sequence; $P_{(i) k}$ is the fixed effect of the $k$ th period $(k=1$ to 3$) ; T_{l}$ is the fixed effect of the $l$ th treatment $(l=1$ to 3$) ; C_{m}$ is the fixed carryover effect from the previous period $(C$ $=0$, if period $=1)$; and $e_{(i j k) l}$ is the random error. If carryover effects were not detected, a simplified model for a replicated Latin square was used:

$$
y_{i j k l}=\mu+S_{i}+A_{(i) j}+P_{(i) k}+T_{l}+e_{(i j k) l},
$$

where $y_{i j k l}$ is the observation for dependent variables; $\mu$ is the general mean; $S_{i}$ is the random effect of the $i$ th square $(i=1$ to 4$) ; A_{(i) j}$ is the random effect of cow nested within square; $P_{(i) k}$ is the fixed effect of the $k$ th period ( $k=1$ to 3 ); $T_{l}$ is the fixed effect of the $l$ th treatment ( $l=1$ to 3 ); and $e_{(i j k) l}$ is the random error. Data for DM and nutrient intake, behavior, milk yield, milk composition, $\mathrm{PD}, \mathrm{MN}$, time of $\mathrm{pH}$ under a threshold value, and hematological and biochemical blood measures were summarized by day. For hematological measures, 2 tubes were not reported by the laboratory due to coagulation of samples; therefore, different standard errors are reported for each treatment. Sampling time (a.m. or p.m. sampling for VFA and $\mathrm{NH}_{3}$ ) and hour (for $\mathrm{pH}$ ) were included as repeated measurements and the interaction of treatment and repeated measurement, with cow as a subject. In case of $\mathrm{pH}$ and $\mathrm{NH}_{3}$, the interaction between dietary treatment and time was not significant, and therefore it was removed from the model. The estimation method was REML and the degrees of freedom method was KenwardRoger. The variance-covariance structure that yielded the lowest corrected Akaike information criterion was compound symmetry, which was selected for the final model. For sensory analysis of milk variables, a completely randomized block design was used, where block corresponded to the experimental period. Orthogonal polynomial contrasts were performed to determine linear and quadratic effects of the inclusion of FR. The IML procedure of SAS (SAS Institute Inc.) was used to generate coefficients adjusted for the unequal spacing of increasing FR inclusion in the diet. All data were 
reported as LSM \pm SEM. Significance was declared at $P \leq 0.05$ and trends at $0.05<P \leq 0.10$.

\section{RESULTS}

\section{Intake, Ingestive Behavior, and Production, Composition, and Sensory Characteristics of Milk}

Dry matter, feed and nutrient intakes, ingestive behavior, and milk production are presented in Table 2 . Grass silage intake was reduced linearly by 4.7 and 6.1 $\mathrm{kg}$ of DM for cows fed $30 \% \mathrm{FR}$ and $45 \%$ FR compared with the control diet $(P<0.001)$ respectively, whereas FR intake increased linearly by 6.0 and $8.4 \mathrm{~kg}$ of DM from the control diet to $30 \% \mathrm{FR}$ and $45 \% \mathrm{FR}(P<$ 0.001). Nevertheless, inclusion of FR in the diet had no effect on total daily DMI or digestible OM intake, which averaged $19.5 \pm 0.2$ and $14.7 \pm 0.2 \mathrm{~kg} / \mathrm{d}$, respectively. Whereas CP intake increased linearly $(P<$ 0.001) with the inclusion of $\mathrm{FR}$ in the diet, a linear decline was observed for OM, aNDFom, and ADFom intakes $(P<0.01)$. Ingestive behavior was altered by the inclusion of $\mathrm{FR}$ in the diet; the time that cows spent eating increased linearly from 252 to $418 \mathrm{~min} / \mathrm{d}$ $(P<0.001)$, whereas rumination time reduced linearly from 539 to $338 \mathrm{~min} / \mathrm{d}$ when including $\mathrm{FR}$ up to $45 \%$ in the diet $(P<0.001)$. The time that cows spent performing other activities showed a quadratic response $(649,634$, and $685 \mathrm{~min} / \mathrm{d}$ for control, $30 \% \mathrm{FR}$, and $45 \%$ FR, respectively; $P=0.036$ )

We detected a linear effect of including $\mathrm{FR}$ in the diet on milk $(P=0.042)$ and lactose yield $(P=0.043)$, and a trend for a linear response for $\operatorname{ECM}(P=0.069)$, fatand protein-corrected milk $(P=0.099)$, and protein

Table 2. Feed and nutrient intake, ingestive behavior, milk yield and milk composition of cows fed with increasing concentrations of forage rape in their diet

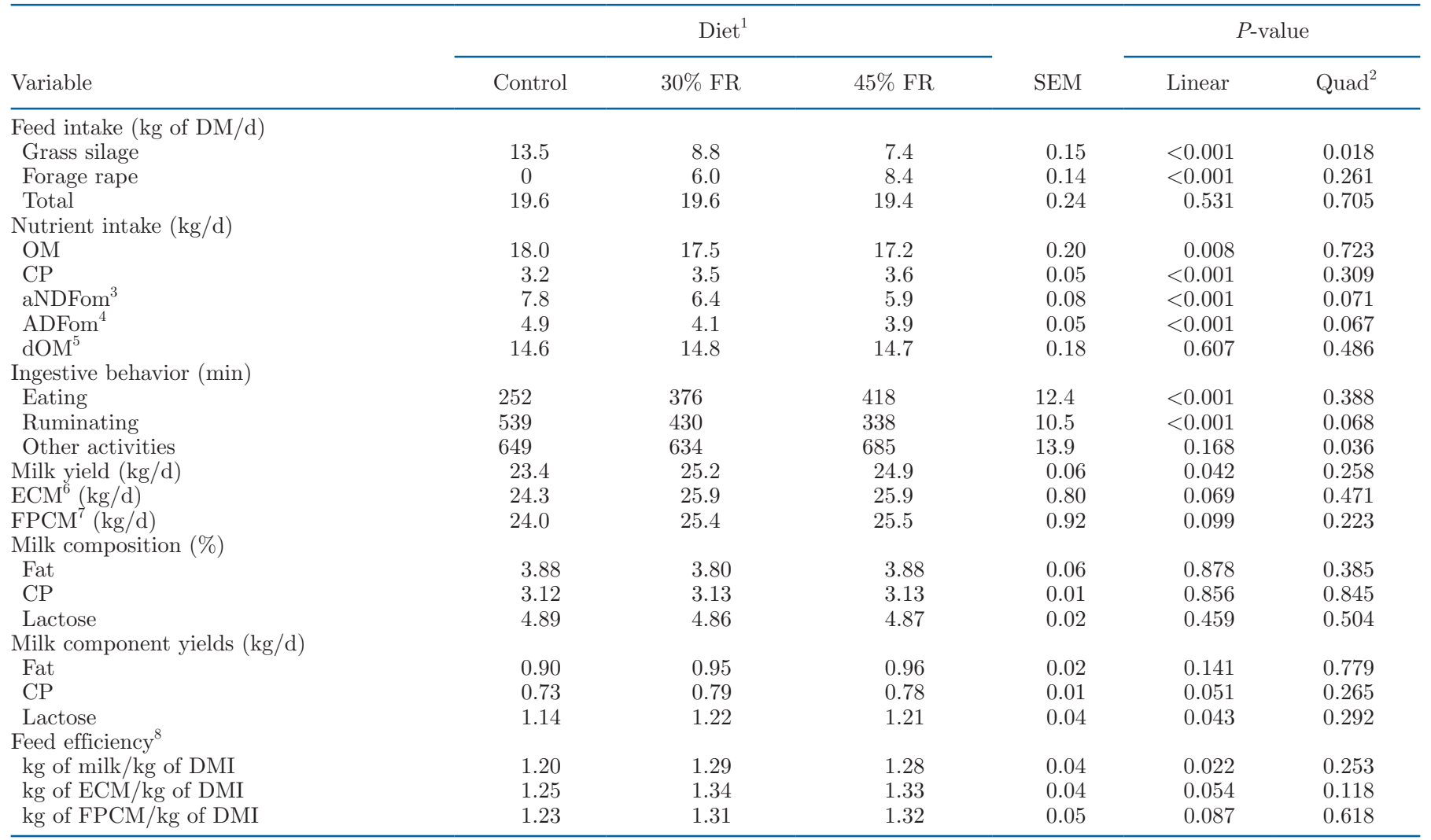

${ }^{1} 30 \% \mathrm{FR}=70 \%$ control diet and $30 \%$ forage rape; $45 \% \mathrm{FR}=55 \%$ control diet and $45 \%$ forage rape.

${ }^{2} \mathrm{Quad}=$ quadratic effects of orthogonal polynomial contrasts.

${ }^{3}$ aNDFom $=$ NDF in the OM.

${ }^{4} \mathrm{ADFom}=\mathrm{ADF}$ in the $\mathrm{OM}$, determined by sequential fiber analysis with correction for residual ash (Cassida et al., 2007).

${ }^{5} \mathrm{dOM}=\mathrm{OM}$ degraded as a $\%$ of original $\mathrm{OM}$.

${ }^{6} \mathrm{ECM}=(12.97 \times \mathrm{kg}$ of fat $)+(7.21 \times \mathrm{kg}$ of protein $)+(0.3273 \times \mathrm{kg}$ of milk $) ;$ Tyrrell and Reid $(1965)$.

${ }^{7}$ Fat- and protein-corrected milk $=$ milk $(\mathrm{kg} / \mathrm{d}) \times(0.1226 \times$ fat $\%+0.0776 \times$ protein $\%+0.2534) ;$ IDF $(2015)$.

${ }^{8}$ Efficiencies calculated as milk $(\mathrm{kg} / \mathrm{d})$, ECM $(\mathrm{kg} / \mathrm{d})$, or FPCM $(\mathrm{kg} / \mathrm{d})$ divided by DMI $(\mathrm{kg} / \mathrm{d})$. 
yield $(P=0.051)$. Concentrations of fat, protein, and lactose in milk, and milk fat yield were not modified by dietary treatments, averaging $3.85 \pm 0.06,3.13 \pm 0.01$, $4.87 \pm 0.02 \%$, and $0.94 \pm 0.02 \mathrm{~kg} / \mathrm{d}$, respectively $(P>$ 0.05 ). Feed efficiency ( $\mathrm{kg}$ of milk/kg of DMI) increased linearly $(P=0.022)$ with inclusion of $\mathrm{FR}$ in the diet, whereas trends toward a linear increase for kilograms of ECM/kilogram of DMI $(P=0.054)$ and kilograms of fat- and protein-corrected milk/kilogram of DMI $(P$ $=0.087$ ) were observed. Milk sensory analyses showed that inclusion of FR in lactating dairy cows diet had no effect $(P>0.05)$ on general flavor, smell, spiciness, or bitterness of milk, with average scores of $6.73 \pm 0.10$, $6.89 \pm 0.15,6.97 \pm 0.12$, and $7.99 \pm 0.12$, respectively (Supplemental Table S1; https://doi.org/10.3168/jds .2020-18785).

\section{Rumen Fermentation, Urinary PD, and N Metabolism}

Results of rumen fermentation measurements are presented in Table 3. There were significant dietary treatment by sampling time interactions for total VFA and molar percentages of propionate, butyrate, isobutyrate, valerate, caproate, and minor VFA $(P<0.05)$. A linear effect of FR inclusion was observed on molar percentages of acetate $(P=0.069)$, isovalerate $(P=$ $0.069)$, and acetate:propionate $(\mathrm{A}: \mathrm{P})$ and (acetate + butyrate):propionate $[(\mathrm{A}+\mathrm{B}): \mathrm{P}]$ ratios $(P<0.001)$. Total VFA concentrations in the rumen were not affected by dietary treatments in the morning but increased in the afternoon with the inclusion of FR $(88,96$, and 100 $\mathrm{m} M$ for control, $30 \% \mathrm{FR}$, and $45 \%$ FR respectively; $P=0.011)$. The inclusion of FR in the diet increased linearly the molar percentage of acetate from 62.2 to $64.1 \mathrm{~mol} / 100 \mathrm{~mol}(P=0.002)$. In the morning, the molar percentage of propionate in the rumen was linearly reduced (from $20.9 \mathrm{~mol} / 100 \mathrm{~mol}$ for cows fed control to $17.9 \mathrm{~mol} / 100 \mathrm{~mol}$ for $45 \% \mathrm{FR}$ ); a linear reduction was also observed in the afternoon, but to a lesser extent (16.9 to $15.0 \mathrm{~mol} / 100 \mathrm{~mol}$ for cows fed control and $45 \% \mathrm{FR}$, respectively; $P<0.001)$. In contrast, butyrate molar percentage in the rumen increased linearly $(P$ $<0.001$ ) in the morning (from 14.4 to $16.5 \mathrm{~mol} / 100$ mol) and in the afternoon but to a lesser extent than in the morning (13.9 to $14.5 \mathrm{~mol} / 100 \mathrm{~mol}$ ). These resulted in linear increases in A:P $(3.93,4.26$, and 4.54 for control, $30 \% \mathrm{FR}$, and $45 \% \mathrm{FR}$, respectively) and $(\mathrm{A}+\mathrm{B}): \mathrm{P}$ ratios $(4.76,5.19$, and 5.52 for control, $30 \%$ FR, and $45 \% \mathrm{FR}$, respectively). Molar percentages of minor VFA (4.38 to $4.73 \mathrm{~mol} / 100 \mathrm{mmol}$ ), isobutyrate (0.95 to $1.01 \mathrm{~mol} / 100 \mathrm{~mol}$ ), and caproate (0.45 to 0.62 $\mathrm{mol} / 100 \mathrm{~mol}$ ) increased linearly with inclusion of FR in the morning; however, no treatment effect was observed in the afternoon. For valerate, there was a quadratic response in the morning $(1.46,1.66$, and $1.67 \mathrm{~mol} / 100$ mol for control, $30 \% \mathrm{FR}$, and $45 \% \mathrm{FR}$, respectively) and a linear increase in the afternoon sampling (1.16, 1.23 , and $1.30 \mathrm{~mol} / 100 \mathrm{~mol}$ for control, $30 \% \mathrm{FR}$, and $45 \%$ FR, respectively). Finally, a linear reduction was observed with inclusion of FR on rumen isovalerate molar percentage $(1.21,1.13$, and 1.12 for control, $30 \%$ $\mathrm{FR}$, and $45 \% \mathrm{FR}$, respectively; $P=0.002$ ).

Mean rumen $\mathrm{pH}$ decreased linearly from 6.10 in the control diet to 6.07 in $45 \% \mathrm{FR}(P<0.001$; Table 4$)$. The daily times with rumen $\mathrm{pH}<5.8$ and $>6.2$ were not affected by dietary treatments $(P>0.05)$, whereas

Table 3. Effect of increasing concentrations of forage rape on total VFA and in the molar proportions of individual VFA in the rumen fluid of lactating dairy cows

\begin{tabular}{|c|c|c|c|c|c|c|c|c|c|}
\hline Variable & \multicolumn{6}{|c|}{$\operatorname{Diet}^{1}$} & SEM & \multicolumn{2}{|c|}{$P$-value } \\
\hline Total VFA $(\mathrm{m} M)$ & 104 & 101 & 105 & 88 & 96 & 100 & 3.26 & 0.011 & 0.401 \\
\hline VFA $(\mathrm{mol} / 100 \mathrm{~mol})$ & & & & & & & & & \\
\hline Acetate (A) & 60.3 & 60.5 & 60.9 & 64.1 & 66.6 & 67.3 & 0.41 & 0.002 & 0.301 \\
\hline Isobutyrate & 0.95 & 0.97 & 1.01 & 0.79 & 0.75 & 0.76 & 0.02 & $<0.001$ & 0.001 \\
\hline Valerate & 1.46 & 1.66 & 1.67 & 1.16 & 1.23 & 1.30 & 0.03 & $<0.001$ & 0.394 \\
\hline Isovalerate & 1.52 & 1.44 & 1.44 & 0.91 & 0.82 & 0.81 & 0.06 & 0.002 & 0.435 \\
\hline Caproate & 0.45 & 0.53 & 0.62 & 0.29 & 0.30 & 0.31 & 0.17 & $<0.001$ & 0.349 \\
\hline Minor $\mathrm{VFA}^{3}$ & 4.38 & 4.60 & 4.73 & 3.15 & 3.10 & 3.18 & 0.08 & 0.002 & 0.412 \\
\hline $\mathrm{A}: \mathrm{P}$ & 2.89 & 3.22 & 3.44 & 3.93 & 4.26 & 4.54 & 0.09 & $<0.001$ & 0.352 \\
\hline$(\mathrm{A}+\mathrm{B}): \mathrm{P}$ & 3.58 & 4.07 & 4.37 & 4.76 & 5.19 & 5.52 & 0.11 & $<0.001$ & 0.436 \\
\hline
\end{tabular}

${ }_{30 \% \mathrm{FR}}=70 \%$ control diet and $30 \%$ forage rape; $45 \% \mathrm{FR}=55 \%$ control diet and $45 \%$ forage rape.

${ }^{2} \mathrm{Quad}=$ quadratic effects of orthogonal polynomial contrasts.

${ }^{3}$ Minor VFA are the sum of isobutyrate, isovalerate, valerate, and caproate. 
Table 4. Effect of increasing concentrations of forage rape in the diet on rumen $\mathrm{pH}$, urinary purine derivative (PD) and $\mathrm{N}$ metabolism of lactating dairy cows

\begin{tabular}{|c|c|c|c|c|c|c|}
\hline \multirow[b]{2}{*}{ Variable } & \multicolumn{3}{|c|}{ Diet $^{1}$} & \multirow[b]{2}{*}{ SEM } & \multicolumn{2}{|c|}{$P$-value } \\
\hline & Control & $30 \% \mathrm{FR}$ & $45 \% \mathrm{FR}$ & & Linear & Quad $^{2}$ \\
\hline $\mathrm{pH}<5.8(\min / \mathrm{d})$ & 249 & 284 & 225 & 71.4 & 0.856 & 0.458 \\
\hline $\mathrm{pH}>5.8$ and $<6.2(\mathrm{~min} / \mathrm{d})$ & 667 & 843 & 820 & 46.0 & 0.029 & 0.238 \\
\hline $\mathrm{pH}>6.2(\mathrm{~min} / \mathrm{d})$ & 535 & 453 & 457 & 70.1 & 0.497 & 0.523 \\
\hline Ammonia (mmol/L) & 8.7 & 10.1 & 10.9 & 0.70 & 0.015 & 0.902 \\
\hline Creatinine $(\mathrm{mmol} / \mathrm{d})$ & 130 & 134 & 131 & 1.51 & 0.339 & 0.202 \\
\hline Total PD excretion $(\mathrm{mmol} / \mathrm{d})$ & 470 & 498 & 486 & 8.36 & 0.081 & 0.156 \\
\hline Predicted microbial $\mathrm{N}^{3}(\mathrm{~g} / \mathrm{d})$ & 308 & 326 & 319 & 5.12 & 0.058 & 0.153 \\
\hline MUN (mg/dL) & 12.5 & 12.7 & 13.0 & 0.12 & 0.027 & 0.734 \\
\hline BUN (mg/dL) & 14.2 & 14.4 & 16.6 & 0.61 & 0.001 & 0.010 \\
\hline Milk $N(g / d)$ & 114 & 123 & 123 & 2.8 & 0.026 & 0.381 \\
\hline Excreted N (g/d) & 435 & 467 & 475 & 12.1 & 0.014 & 0.647 \\
\hline
\end{tabular}

${ }^{1} 30 \% \mathrm{FR}=70 \%$ control diet and $30 \%$ forage rape; $45 \% \mathrm{FR}=55 \%$ control diet and $45 \%$ forage rape.

${ }^{2} \mathrm{Quad}=$ quadratic effects of orthogonal polynomial contrasts.

${ }^{3}$ Predicted assuming daily purine derivative excretion $\left(\mathrm{dPD} ; \mathrm{mmol} / \mathrm{kg}\right.$ of $\left.\mathrm{BW}^{0.75}\right)=\mathrm{PD}$ index $\times 0.9$; daily absorbed purines $($ daP $)=[\mathrm{dPD}$ $\left(\mathrm{mmol} / \mathrm{kg}\right.$ of $\left.\left.\mathrm{BW}^{0.75}\right)-0.385 \times \mathrm{BW}^{0.75}\right]+0.85 ;$ and microbial $\mathrm{N}(\mathrm{g}$ of $\mathrm{N} / \mathrm{d})=(\mathrm{daP} \times 70) /(0.116 \times 0.83 \times 1,000)$.

the daily time with $\mathrm{pH}$ between 5.8 and 6.2 had a linear increase of $153 \mathrm{~min} / \mathrm{d}$ from control to $45 \% \mathrm{FR}(P=$ 0.029).

Results of urinary PD and $\mathrm{N}$ metabolism are presented in Table 4. Rumen $\mathrm{NH}_{3}$ concentration had a linear increase $(P=0.015)$ from cows fed the control diet $(8.7 \mathrm{mmol} / \mathrm{L})$ to those fed $45 \% \mathrm{FR}(10.9 \mathrm{mmol} / \mathrm{L})$. Although dietary treatments had no effect on allantoin and creatinine daily excretions, uric acid $(P=0.053)$ and total PD excretions $(P=0.081)$ tended to increase linearly, which resulted in a trend toward a linear increase in predicted $\mathrm{MN}(P=0.058)$ with the inclusion of FR in the diet. Concentrations of BUN $(P=0.001)$ and MUN $(P=0.027)$ increased linearly from 14.2 to $16.6 \mathrm{mg} / \mathrm{dL}$ and from 12.5 to $13.0 \mathrm{mg} / \mathrm{dL}$, respectively. Milk $(P=0.026)$ and excreted $\mathrm{N}(P=0.014)$ from cows showed a linear increase up to 9 and $40 \mathrm{~g} / \mathrm{d}$, respectively, with the inclusion of $45 \%$ of FR. The $\mathrm{N}$ use efficiency of dairy cows was not affected by the inclusion of FR, averaging $20.9 \pm 0.6 \%$ among treatments.

\section{Hematological and Biochemical Blood Measures}

Hematological measurements such as RBC, Hb, PCV, MCV, MCHC, eosinophils, and lymphocytes were not affected by dietary treatments, whereas neutrophils and leukocytes increased linearly with inclusion of FR in the $\operatorname{diet}(P<0.001)$, and a trend for a linear increase was observed for monocytes $(P=0.082$; Table 5$)$. Among liver enzymes, GGT activity was not affected by dietary treatments, AST activity tended to decrease linearly $(P=0.069)$, and GLDH concentrations showed a quadratic response $(P=0.029)$, with $57.1,32.9$, and $49.6 \mathrm{U} / \mathrm{L}$ for control, $30 \% \mathrm{FR}$, and $45 \% \mathrm{FR}$, respectively. Lipid mobilization metabolites (NEFA and BHB) and thyroid function $\left(\mathrm{T}_{3}\right.$ and $\left.\mathrm{T}_{4}\right)$ were not affected by dietary treatments $(P>0.05)$. Furthermore, no Heinz bodies were detected in blood from cows fed any of the dietary treatments.

\section{DISCUSSION}

The aim of this study was to determine DMI, rumen fermentation, health status, milk sensory characteristics, and production responses of mid-lactating dairy cows fed diets containing increasing percentages (30 and $45 \%$ ) of FR in the diet. Including FR up to $45 \%$ in the diet of dairy cows improved milk performance without causing negative effects on dairy cow health status or on milk sensory properties. It is worth noting that observations of feeding behavior and sampling of urine, blood, and rumen fluid were performed once per experimental period; thus, daily variation in these measurements may have not been captured.

\section{DMI and Ingestive Behavior}

Total DMI was not affected by treatments, which indicates that inclusion of FR up to $45 \%$ of the diet did not limit intake. The lack of effect on total DMI could be associated with the longer time spent eating by cows offered FR in the diet. As total eating time increased with FR inclusion, ruminating time was reduced. Williams et al. (2016) also reported similar DMI between 
cows fed with and without FR. However, a reduction in the DMI of dairy cows has been reported when FR was included at $25 \%$ of the diet (Castillo-Umaña et al., 2020). Thus, other factors such as secondary metabolites, water content, and type of diet could influence the effect of FR on DMI (Barry, 2013). For example, the high water content and bulkiness of brassicas increase the fresh weight that animals have to ingest, which may affect eating time (Stefanski et al., 2010). As in our study, Castillo-Umaña et al. (2020) reported an increase in eating time and a reduction in rumination time. This increase in eating time may also be partly due to cows sorting and choosing leaves over stems (Stefanski et al., 2010). The lower DMI for cows fed FR diets reported by those authors may differ from our results (no reduction in DMI with FR inclusion) because of the lower time that cows had access to FR ( 5 vs. $17 \mathrm{~h}$ ) and because FR was offered in 1 meal, whereas in the current study it was offered in 2 meals. Behavioral adaptations of cows may be insufficient to maintain daily intake when time at pasture is restricted to less than $8 \mathrm{~h}$ (Pérez-Ramírez et al., 2008). The reduction in rumination time may also be explained as a behavioral adaptation of cows to increased eating time. Moreover, it might be affected by the lower aNDFom intake of cows fed FR, because lower fiber intakes are usually associated with lower rumination time (Zebeli et al., 2012).

\section{Production, Composition, and Sensory Characteristics of Milk}

Although DMI was not affected by FR inclusion, milk production increased linearly with the inclusion of up to $45 \% \mathrm{FR}$ in the diet. The linear increase in feed efficiency ( $\mathrm{kg}$ of milk/ $\mathrm{kg}$ of DMI) for cows fed FR may be related to the greater intake of readily fermentable carbohydrates, the increase in total VFA concentration in the rumen, and the tendency to a greater MN flow. Castillo-Umaña et al. (2020) and our study both show an increase in feed efficiency with the inclusion of FR. These indications of greater efficiency suggest that replacing grass silage and purchased concentrates with FR may reduce feeding costs and farm profitability might therefore be increased, because the cost per kilogram DM of purchased concentrates is about 2.5 times that of brassicas (Eckard et al., 2001).

Williams et al. (2016) reported that the inclusion of FR in the diet increased milk production in lactating dairy cows in response to a greater ME intake. In the present study, partial replacement of grass silage with

Table 5. Effect of increasing concentrations of forage rape in the diet on hematological and biochemical health metabolites of lactating dairy cows

\begin{tabular}{|c|c|c|c|c|c|}
\hline Metabolite $^{1}$ & \multicolumn{3}{|c|}{$\operatorname{Diet}^{2}$} & \multicolumn{2}{|c|}{$P$-value } \\
\hline $\mathrm{RBC}\left(\times 10^{6} / \mu \mathrm{L}\right)$ & $4.8 \pm 0.2$ & $5.4 \pm 0.3$ & $4.9 \pm 0.2$ & 0.547 & 0.928 \\
\hline Hemoglobin (g/dL) & $8.1 \pm 0.2$ & $8.3 \pm 0.2$ & $8.1 \pm 0.22$ & 0.907 & 0.348 \\
\hline PCV (\%) & $24.8 \pm 0.7$ & $26.0 \pm 0.8$ & $25.0 \pm 0.7$ & 0.673 & 0.243 \\
\hline MCV (fL) & $53.8 \pm 1.9$ & $53.4 \pm 2.0$ & $53.3 \pm 1.9$ & 0.762 & 0.968 \\
\hline Eosinophils $($ cells $/ \mu \mathrm{L})$ & $457 \pm 74$ & $460 \pm 79$ & $420 \pm 74$ & 0.693 & 0.727 \\
\hline Neutrophils $($ cells $/ \mu \mathrm{L})$ & $2,606 \pm 335$ & $3,308 \pm 392$ & $3,911 \pm 324$ & $<0.001$ & 0.575 \\
\hline Lymphocytes (cells/ $\mu \mathrm{L})$ & $3,335 \pm 261$ & $3,306 \pm 278$ & $3,009 \pm 261$ & 0.272 & 0.451 \\
\hline Monocytes (cells/ $\mu \mathrm{L})$ & $367 \pm 67$ & $489 \pm 74$ & $539 \pm 67$ & 0.082 & 0.210 \\
\hline \multicolumn{6}{|l|}{ Biochemical } \\
\hline NEFA (mmol/L) & $0.14 \pm 0.02$ & $0.15 \pm 0.02$ & $0.15 \pm 0.02$ & 0.853 & 0.924 \\
\hline $\mathrm{BHB}(\mathrm{mmol} / \mathrm{L})$ & $0.55 \pm 0.05$ & $0.508 \pm 0.05$ & $0.570 \pm 0.05$ & 0.926 & 0.251 \\
\hline Heinz bodies (\%) & $\mathrm{ND}^{4}$ & ND & ND & - & - \\
\hline
\end{tabular}

${ }^{1} \mathrm{PCV}=$ hematocrit; $\mathrm{RBC}=$ red blood cell count; $\mathrm{WBC}=$ white blood cell count; $\mathrm{MCV}=$ mean corpuscular volume; $\mathrm{MCHC}=$ mean corpus cular hemoglobin volume; NEFA = nonesterified fatty acids; GGT $=\gamma$-glutamyl transpeptidase; AST $=$ aspartate aminotransferase; GLDH $=$ glutamate dehydrogenase; $\mathrm{T}_{3}=$ tri-iodothyronine; $\mathrm{T}_{4}=$ thyroxine.

${ }^{2} 30 \% \mathrm{FR}=70 \%$ control diet and $30 \%$ forage rape; $45 \% \mathrm{FR}=55 \%$ control diet and $45 \%$ forage rape.

${ }^{3} \mathrm{Quad}=$ quadratic effects of orthogonal polynomial contrasts.

${ }^{4} \mathrm{ND}=$ not detected. 
FR increased NFC concentration in the diet. Considering that the NFC present in FR are rapidly fermentable ( $>50 \%$ of sugar, starch, and soluble fiber that degrade at rates of 16 to $20 \% / \mathrm{h}$; Keim et al., 2019), these may have led to the greater total VFA concentration in the rumen of cows fed FR (Getachew et al., 2004). Moreover, inclusion of FR in the diet consistently increases butyrate molar percentage (Williams et al., 2016; Castillo-Umaña et al., 2020). According to Seymour et al. (2005), the greater energy intake of cows is channeled largely through increases in rumen production of butyrate and propionate and their yield of ATP to the host animal. Finally, the tendency to greater MN flow suggests a greater supply of MP and may explain differences in milk yield, as MN is the major contributor to MP (Schwab and Broderick, 2017). Increasing MP supply up to $9.7 \%$ of DMI has been shown to increase milk production (Wang et al., 2007).

The lack of changes in milk composition with FR inclusion in the diet is in accordance with Williams et al. (2016) and Castillo-Umaña et al. (2020) under alfalfa hay and grass silage-based diets, respectively. Evaluation of the sensory characteristics of milk products has been the ultimate method for evaluating product quality (Schiano et al., 2017). It has been proposed that inclusion of brassicas in the diet may affect milk sensory characteristics, such as flavor and odor, because thiocyanate from brassicas has been found to pass into milk and result in flavor defects (Wiedenhoeft and Barton, 1995). Thiocyanates are quickly absorbed and passed into milk; therefore, it is recommended to remove brassicas from cows $4 \mathrm{~h}$ before milking to reduce this negative effect (Moate et al., 1996). Moreover, inclusion of FR has been found to modify the fatty acids profile of milk (Williams et al., 2016; Seguel et al., 2020), which can result in oxidized flavors in fluid milk (Schiano et al., 2017). In the present study, the judging panel was unable to detect differences in the sensory characteristics of milk (flavor, smell, spiciness, and bitterness) following inclusion of FR in dairy cow diets. This agrees with previous research reporting that cheeses made of milk from brassica-fed cows were similar in flavor and texture to those made from milk of cows without brassicas in their diet, and no bitter flavors or taint were detected (Moate et al., 1996; Seguel et al., 2020).

\section{Rumen Fermentation, Urinary PD, and N Metabolism}

After feeding FR, a linear increase in total VFA was observed, which, as stated earlier, is related to the greater concentrations of readily fermentable carbohydrates in FR compared with grass silage. According to Keim et al. (2019), FR contains between 100 and $130 \mathrm{~g} / \mathrm{kg}$ of sugars and $>300 \mathrm{~g} / \mathrm{kg}$ DM of soluble fiber, with $90 \mathrm{~g} / \mathrm{kg}$ DM of pectins (Sun et al., 2012). Greater inclusion of sugars in lactating dairy cow diets results in greater rumen butyrate concentrations (Oba, 2011), whereas soluble fiber is expected to increase acetate in the rumen (Zhao et al., 2013). This would explain the greater proportions of acetate and butyrate obtained in the rumen of FR-fed cows. Furthermore, fermentable starch increases propionate concentration in the rumen (Oba et al., 2015); thus, the lower propionate concentration in the rumen may be due to the lower starch concentrations in FR diets, in which the inclusion of grain-based concentrate was reduced. The linear increase in minor VFA with the inclusion of FR may be attributed to the greater $\mathrm{CP}$ intake by cows with FR in their diets. In the rumen, minor VFA are produced via deamination and decarboxylation processes of the branched-chain AA from feed or microbial protein (Liu et al., 2018).

Dairy cows that are allocated to high allowances of FR preferentially consume leaves over stems (Stefanski et al., 2010) and may be at greater risk of SARA because of the low NDF and high readily fermentable carbohydrate concentrations of FR. Thus, it has been recommended to include brassicas as a minor proportion $(0.2-0.3)$ of the dairy cow diet to dilute secondary compounds in the diet and to prevent SARA (Westwood and Mulcock, 2012; Barry, 2013). Although intake of NDF was lower for cows fed FR, this had no effect on the daily amount of time with $\mathrm{pH}$ below 5.8. Although sugars and soluble fiber are readily and extensively broken down in the rumen, they do not mimic the $\mathrm{pH}-$ lowering effect of starch and do not produce lactate and rumen $\mathrm{pH}$ reduction as starch does (Hall et al., 1998; Oba et al., 2015). Moreover, it has been proposed that the bulkiness of brassicas may increase saliva production, which buffers changes in rumen $\mathrm{pH}$ (Keogh et al., 2009). The time that rumen $\mathrm{pH}$ was below 5.8 was averaged $250 \mathrm{~min} / \mathrm{d}$ for all treatments; thus, FR inclusion up to $45 \%$ in the diet is not expected to induce SARA, which is defined as a daily decrease in $\mathrm{pH}<5.8$ from 284 to $475 \mathrm{~min} / \mathrm{d}$ (AlZahal et al., 2007).

Although diets in this study were formulated to be isonitrogenous, the greater $\mathrm{N}$ intake may have been due to selection by dairy cows for leaves over stems of FR (Stefanski et al., 2010), as the CP concentration is $\sim 5$ percentage units greater in FR leaves than in stems (Keim et al., 2020). This CP degrades rapidly $(0.34 / \mathrm{h})$ and to a high extent (85\% effective degradability, calculated with a 0.06 passage rate; Keim et al., 2019), increasing the supply of degradable protein in the rumen that produces $\mathrm{NH}_{3}$. Ammonia is toxic to rumen microorganisms and to the host animal; therefore, it is transported from the rumen to the liver to be converted into urea (Abdoun et al., 2006; Pacheco and 
Waghorn, 2008). Furthermore, the trend for a linear increase in $\mathrm{MN}$ flow suggests a greater supply of AA in the small intestine. Amino acids that are surplus to requirements will be catabolized and contribute to the urea pool (Lapierre et al., 2005). In contrast to our results, Castillo-Umaña et al. (2020) observed that inclusion of $25 \% \mathrm{FR}$ in the diet had no effect on $\mathrm{N}$ intake and reduced rumen $\mathrm{NH}_{3}$ concentrations, which might be explained by the greater $\mathrm{CP}$ concentrations in grass silage and lower $\mathrm{CP}$ concentrations in $\mathrm{FR}$ in their study. The literature shows that CP concentration of FR is highly variable and ranges between 10.8 and $27.6 \%$ of DM (Keim et al., 2019). As observed in a previous study, MN flow tends to increase with FR (Castillo-Umaña et al., 2020), which might be due to the greater energy supply in the rumen from the fast fermentation rates of their carbohydrates (Keim et al., 2019) or to changes in microbial communities (Sun et al., 2015). These effects resulted in greater retention of $\mathrm{N}$ in milk. However, this was accompanied by greater $\mathrm{N}$ excretion and no improvement in $\mathrm{N}$ use efficiency, as greater $\mathrm{N}$ intakes may increase both excreted and milk N (Kebreab et al., 2002).

\section{Hematological and Biochemical Blood Measurements}

Forage rape contains SMCO and glucosinolates, which can produce negative effects in animals (Chorfi et al., 2015). Fermentation of SMCO in the rumen produces dimethyl disulfide, which can inactivate $\mathrm{Hb}$ and induce anemia (Barry, 2013). Indicators of anemia (hematocrit, $\mathrm{Hb}$, and $\mathrm{RBC}$ counts) were similar between cows fed with and without FR. Also, the absence of Heinz bodies suggests that inclusion of FR up to $45 \%$ was not associated with short-term negative effects from SMCO. Glucosinolates are fermented in the rumen into isothiocyanates, which can affect function of thyroid hormones (Barry, 2013). However, the concentrations of $T_{3}$ and $T_{4}$ were not modified by inclusion of $F R$ in the diet. Similar results were reported by Castillo-Umaña et al. (2020), where inclusion of FR at $25 \%$ of the diet was not associated with anemia or altered thyroid function. Neutrophil count is a simple measurement to assess the inflammatory status of an animal (Moretti et al., 2015). In this study, WBC counts showed a greater increase, driven by higher neutrophil counts in cows fed FR; however, these values were within the normal range for adult cows $\left(4.4-10.8\right.$ and $0.8-5.0 \times 10^{3} / \mu \mathrm{L}$ for WBC and neutrophils, respectively; Herman et al., 2018). Thus, the increased leukocytes and especially neutrophils in FR-fed cows may not be associated with inflammatory alterations. Liver health was evaluated according to enzymes released in response to liver cell damage; that is, AST, GLDH, and GGT (Bionaz et al., 2007). Even though AST and GLDH tended to be reduced with the inclusion of $\mathrm{FR}$ in the diet, the values in all treatments were within the reference limits indicated by Noro et al. (2013; <110 and 30 U/L for AST and GLDH, respectively). Moreover, the similar concentrations of GGT suggest that in this study, liver cells were not affected by inclusion of FR, as previously reported by Cox-Ganser et al. (1994).

\section{CONCLUSIONS}

The inclusion of FR in dairy cow diets modified nutrient intake and feeding behavior and improved production efficiency and ruminal fermentation, possibly associated with the greater supply of rumen fermentable carbohydrates and microbial protein synthesis. Moreover, no negative effects associated with the health status of cows or sensory characteristics of milk were observed with inclusion of up to $45 \%$. We conclude that, under similar feeding conditions, FR can be included up to $45 \%$ in the diet and has the potential to improve milk production efficiency without negative effects on animal health or milk characteristics of midlactation dairy cows.

\section{ACKNOWLEDGMENTS}

This study was sponsored by research grant 11150538 from FONDECYT (Fondo Nacional de Desarrollo Científico y Tecnológico, Chile). The authors have not stated any conflicts of interest.

\section{REFERENCES}

Abdoun, K., F. Stumpff, and H. Martens. 2006. Ammonia and urea transport across the rumen epithelium: A review. Anim. Health Res. Rev. 7:43-59. https://doi.org/10.1017/S1466252307001156.

AlZahal, O., E. Kebreab, J. France, and B. W. McBride. 2007. A mathematical approach to predicting biological values from ruminal pH measurements. J. Dairy Sci. 90:3777-3785. https://doi.org/ 10.3168/jds.2006-534.

AOAC International. 1996. Official Methods of Analysis. 16th ed. AOAC International, Washington, DC.

Barry, T. N. 2013. The feeding value of forage brassica plants for grazing ruminant livestock. Anim. Feed Sci. Technol. 181:15-25. https: //doi.org/10.1016/j.anifeedsci.2013.01.012.

Bionaz, M., E. Trevisi, L. Calamari, F. Librandi, A. Ferrari, and G. Bertoni. 2007. Plasma paraoxonase, health, inflammatory conditions, and liver function in transition dairy cows. J. Dairy Sci. 90:1740-1750. https://doi.org/10.3168/jds.2006-445.

Cassida, K. A., K. E. Turner, J. G. Foster, and O. B. Hesterman. 2007 Comparison of detergent fiber analysis methods for forages high in pectin. Anim. Feed Sci. Technol. 135:283-295. https://doi.org/10 .1016/j.anifeedsci.2006.07.004.

Castillo-Umaña, M. A., O. Balocchi, R. Pulido, P. Sepulveda-Varas, D. Pacheco, S. Muetzel, R. Berthiaume, and J. P. Keim. 2020. Milk production responses and rumen fermentation of dairy cows supplemented with summer brassicas. Animal 14:1684-1692. https:// doi.org/10.1017/S175173112000021X. 
Chorfi, Y., Y. Couture, G. F. Tremblay, R. Berthiaume, and D. CinqMars. 2015. Growth and blood parameters of weaned crossbred beef calves fed forage kale (Brassica oleracea ssp. acephala). Adv. Agric. 2015:1-7. https://doi.org/10.1155/2015/410497.

Cox-Ganser, J. M., G. A. Jung, R. T. Pushkin, and R. L. Reid. 1994. Evaluation of brassicas in grazing systems for sheep. 2. Blood composition and nutrient status. J. Anim. Sci. 72:1832-1841. https:// doi.org/10.2527/1994.7271832x.

Eckard, R. J., A. A. Salardini, M. Hannah, and D. R. Franks. 2001. The yield, quality and irrigation response of summer forage crops suitable for a dairy pasture renovation program in north-western Tasmania. Aust. J. Exp. Agric. 41:37-44. https://doi.org/10.1071/ EA00053.

Garcia, S. C., W. J. Fulkerson, and S. U. Brookes. 2008. Dry matter production, nutritive value and efficiency of nutrient utilization of a complementary forage rotation compared to a grass pasture system. Grass Forage Sci. 63:284-300. https://doi.org/10.1111/j $.1365-2494.2008 .00636 . x$.

Getachew, G., P. H. Robinson, E. J. DePeters, and S. J. Taylor. 2004. Relationships between chemical composition, dry matter degradation and in vitro gas production of several ruminant feeds. Anim. Feed Sci. Technol. 111:57-71. https://doi.org/10.1016/S0377 -8401(03)00217-7.

Hall, A., A. N. Pell, and L. E. Chase. 1998. Characteristics of neutral detergent-soluble fiber fermentation by mixed ruminal microbes. Anim. Feed Sci. Technol. 70:23-39. https://doi.org/10.1016/S0377 -8401(97)00068-0.

Herman, N., C. Trumel, A. Geffré, J. Braun, M. Thibault, F. Schelcher, and N. Bourgès-Abella. 2018. Hematology reference intervals for adult cows in France using the Sysmex XT-2000iV analyzer. J. Vet. Diagn. Invest. 30:678-687. https://doi.org/10.1177/ 1040638718790310.

IDF (International Dairy Federation). 2015. A common carbon footprint approach for dairy: The IDF guide to standard lifecycle assessment methodology for the dairy sector. Bulletin no. 445. IDF, Brussels, Belgium.

Kaur, R., S. C. Garcia, W. J. Fulkerson, and I. Barchia. 2010. Utilisation of forage rape (Brassica napus) and Persian clover (Trifolium resupinatum) diets by sheep: Effects on whole tract digestibility and rumen parameters. Anim. Prod. Sci. 50:59-67. https://doi .org/10.1071/EA08309.

Kaur, R., S. C. Garcia, W. J. Fulkerson, and I. M. Barchia. 2011. Degradation kinetics of leaves, petioles and stems of forage rape (Brassica napus) as affected by maturity. Anim. Feed Sci. Technol. 168:165-178. https://doi.org/10.1016/j.anifeedsci.2011.04.093.

Kebreab, E., J. France, J. A. N. Mills, R. Allison, and J. Dijkstra. 2002. A dynamic model of $\mathrm{N}$ metabolism in the lactating dairy cow and an assessment of impact of $\mathrm{N}$ excretion on the environment. J. Anim. Sci. 80:248-259. https://doi.org/10.2527/2002.801248x.

Keim, J. P., J. Cabanilla, O. A. Balocchi, R. G. Pulido, and A. Bertrand. 2019. In vitro fermentation and in situ rumen degradation kinetics of summer forage brassica plants. Anim. Prod. Sci. 59:1271-1280. https://doi.org/10.1071/AN17534.

Keim, J. P., M. Gandarillas, D. Benavides, J. Cabanilla, R. G. Pulido, O. A. Balocchi, and A. Bertrand. 2020. Nutrient concentrations and profile of non-structural carbohydrates vary among different Brassica forages. Anim. Prod. Sci. https://doi.org/10.1071/ AN19472.

Keogh, B., P. French, J. J. Murphy, J. F. Mee, T. McGrath, T. Storey, J. Grant, and F. J. Mulligan. 2009. A note on the effect of dietary proportions of kale (Brassica oleracea) and grass silage on rumen $\mathrm{pH}$ and volatile fatty acid concentrations in dry dairy cows. Livest. Sci. 126:302-305. https://doi.org/10.1016/j.livsci.2009.06.010.

Lambert, M. G., S. M. Abrams, H. W. Harpster, and G. A. Jung. 1987. Effect of hay substitution on intake and digestibility of forage rape (Brassica napus) fed to lambs. J. Anim. Sci. 65:1639-1646. https:/ /doi.org/10.2527/jas1987.6561639x.

Lapierre, H., R. Berthiaume, G. Raggio, M. C. Thivierge, L. Doepel, D. Pacheco, P. Dubreuil, and G. E. Lobley. 2005. The route of absorbed nitrogen into milk protein. Anim. Sci. 80:11-22. https:// doi.org/10.1079/ASC41330011.
Lindberg, J. E. 1989. Nitrogen-metabolism and urinary-excretion of purines in goat kids. Br. J. Nutr. 61:309-321. https://doi.org/10 $.1079 /$ BJN19890119.

Liu, Q., C. Wang, G. Guo, W. J. Huo, S. L. Zhang, C. X. Pei, Y. L. Zhang, and H. Wang. 2018. Effects of branched-chain volatile fatty acids on lactation performance and mRNA expression of genes related to fatty acid synthesis in mammary gland of dairy cows. Animal 12:2071-2079. https://doi.org/10.1017/S1751731118000113.

Moate, P. J., D. E. Dalley, C. Grainger, A. Goudy, T. Clarke, P. Williams, and G. Limsowtin. 1996. The effect of feeding turnips on the concentration of thiocyanate in milk and consequences for cheese making. Aust. J. Dairy Technol. 51:1-5.

Moretti, P., M. Probo, N. Morandi, E. Trevisi, A. Ferrari, A. Minuti, M. Venturini, S. Paltrinieri, and A. Giordano. 2015. Early postpartum hematological changes in Holstein dairy cows with retained placenta. Anim. Reprod. Sci. 152:17-25. https://doi.org/10.1016/ j.anireprosci.2014.11.019.

Noro, M., P. T. Cid, C. F. Wagemann, V. V. Arnés, and F. M. Wittwer. 2013. Valoración diagnóstica de enzimas hepáticas en perfiles bioquímicos sanguíneos de vacas lecheras. Revi. Mvz Córdoba 18:3474-3479. https://doi.org/10.21897/rmvz.170.

NRC. 2001. Nutrient Requirements of Dairy Cattle. 7th rev. ed. The National Academies Press, Washington, DC.

Oba, M. 2011. Review: Effects of feeding sugars on productivity of lactating dairy cows. Can. J. Anim. Sci. 91:37-46. https://doi.org/ 10.4141/CJAS10069.

Oba, M., J. L. Mewis, and Z. Zhining. 2015. Effects of ruminal doses of sucrose, lactose, and corn starch on ruminal fermentation and expression of genes in ruminal epithelial cells. J. Dairy Sci. 98:586594. https://doi.org/10.3168/jds.2014-8697.

Pacheco, D., and G. C. Waghorn. 2008. Dietary nitrogen-Definitions, digestion, excretion and consequences of excess for grazing ruminants. Proc. N. Z. Grassl. Assoc. 70:107-116.

Pérez-Ramírez, E., R. Delagarde, and L. Delaby. 2008. Herbage intake and behavioural adaptation of grazing dairy cows by restricting time at pasture under two feeding regimes. Animal 2:1384-1392. https://doi.org/10.1017/S1751731108002486.

Schiano, A. N., W. S. Harwood, and M. A. Drake. 2017. A 100-Year Review: Sensory analysis of milk. J. Dairy Sci. 100:9966-9986. https://doi.org/10.3168/jds.2017-13031.

Schwab, C. G., and G. A. Broderick. 2017. A 100-Year Review: Protein and amino acid nutrition in dairy cows. J. Dairy Sci. 100:1009410112. https://doi.org/10.3168/jds.2017-13320.

Seguel, G., J. P. Keim, E. Vargas-Bello-Perez, C. Geldsetzer-Mendoza, R. Ibañez, and C. Alvarado-Gilis. 2020. Effect of forage brassicas in dairy cow diets on the fatty acid profile and sensory characteristics of Chanco and ricotta cheeses. J. Dairy Sci. 103:228-241. https://doi.org/10.3168/jds.2019-17167.

Seymour, W. M., D. R. Campbell, and Z. B. Johnson. 2005. Relationships between rumen volatile fatty acid concentrations and milk production in dairy cows: A literature study. Anim. Feed Sci. Technol. 119:155-169. https://doi.org/10.1016/j.anifeedsci.2004 .10 .001 .

Stefanski, E. P., S. C. Garcia, S. R. Farina, D. K. Y. Tan, and D. Tanner. 2010. Effects of sowing rate and grazing management of forage rape (Brassica napus) on grazing behaviour and utilisation by dairy cattle. Anim. Prod. Sci. 50:560-567. https://doi.org/10 .1071/AN09206.

Sun, X. Z., G. Henderson, F. Cox, G. Molano, S. J. Harrison, D. Luo, P. H. Janssen, and D. Pacheco. 2015. Lambs fed fresh winter forage rape (Brassica napus L.) emit less methane than those fed perennial ryegrass (Lolium perenne L.), and possible mechanisms behind the difference. PLoS One 10:e0119697. https://doi.org/10 .1371/journal.pone.0119697.

Sun, X. Z., G. C. Waghorn, S. O. Hoskin, S. J. Harrison, S. Muetzel, and D. Pacheco. 2012. Methane emissions from sheep fed fresh brassicas (Brassica spp.) compared to perennial ryegrass (Lolium perenne). Anim. Feed Sci. Technol. 176:107-116. https://doi.org/ 10.1016/j.anifeedsci.2012.07.013.

Tavendale, M. H., L. P. Meagher, D. Pacheco, N. Walker, G. T. Attwood, and S. Sivakumaran. 2005. Methane production from 
in vitro rumen incubations with Lotus pedunculatus and Medicago sativa, and effects of extractable condensed tannin fractions on methanogenesis. Anim. Feed Sci. Technol. 123-124:403-419. https: //doi.org/10.1016/j.anifeedsci.2005.04.037.

Tilley, J. M. A., and R. A. Terry. 1963. A two-stage technique for the in vitro digestion of forage crops. Grass Forage Sci. 18:104-111. https://doi.org/10.1111/j.1365-2494.1963.tb00335.x.

Totty, V. K., S. L. Greenwood, R. H. Bryant, and G. R. Edwards. 2013. Nitrogen partitioning and milk production of dairy cows grazing simple and diverse pastures. J. Dairy Sci. 96:141-149. https://doi.org/10.3168/jds.2012-5504.

Tyrrell, H. F., and J. T. Reid. 1965. Prediction of the energy value of cow's milk. J. Dairy Sci. 48:1215-1223. https://doi.org/10.3168/ jds.S0022-0302(65)88430-2.

Van Soest, P. J., J. B. Robertson, and B. A. Lewis. 1991. Methods for dietary fiber, neutral detergent fiber, and nonstarch polysaccharides in relation to animal nutrition. J. Dairy Sci. 74:3583-3597. https://doi.org/10.3168/jds.S0022-0302(91)78551-2.

Wang, C., J. X. Liu, Z. P. Yuan, Y. M. Wu, S. W. Zhai, and H. W. Ye. 2007. Effect of level of metabolizable protein on milk production and nitrogen utilization in lactating dairy cows. J. Dairy Sci. 90:2960-2965. https://doi.org/10.3168/jds.2006-129.

Weatherburn, M. 1967. Phenol-hypochlorite reaction for determination of ammonia. Anal. Chem. 39:971-974. https://doi.org/10 $.1021 /$ ac60252a045.

Westwood, C. T., and H. Mulcock. 2012. Nutritional evaluation of five species of forage brassica. Proc. N. Z. Grassl. Assoc. 74:31-38.

Wiedenhoeft, M. H., and B. A. Barton. 1995. Taste quality of milk from dairy-cows fed forage brassica cv Tyfon. J. Sustain. Agric. 5:139-146. https://doi.org/10.1300/J064v05n03_11.
Williams, S. R. O., P. J. Moate, M. H. Deighton, M. C. Hannah, W. J. Wales, and J. L. Jacobs. 2016. Milk production and composition, and methane emissions from dairy cows fed lucerne hay with forage brassica or chicory. Anim. Prod. Sci. 56:304-311. https://doi .org/10.1071/AN15528.

Zebeli, Q., J. R. Aschenbach, M. Tafaj, J. Boguhn, B. N. Ametaj, and W. Drochner. 2012. Invited review: Role of physically effective fiber and estimation of dietary fiber adequacy in high-producing dairy cattle. J. Dairy Sci. 95:1041-1056. https://doi.org/10.3168/ jds.2011-4421.

Zhao, X. H., C. J. Liu, Y. Liu, C. Y. Li, and J. H. Yao. 2013. Effects of replacing dietary starch with neutral detergent-soluble fibre on ruminal fermentation, microbial synthesis and populations of ruminal cellulolytic bacteria using the rumen simulation technique (RUSITEC). J. Anim. Physiol. Anim. Nutr. (Berl.) 97:1161-1169. https://doi.org/10.1111/jpn.12025.

\section{ORCIDS}

J. P. Keim @ https://orcid.org/0000-0003-4277-6491

J. Daza (ㄴ) https://orcid.org/0000-0002-9770-6194

I. Beltrán ( ) https://orcid.org/0000-0002-1062-1017

O. A. Balocchi ๑ https://orcid.org/0000-0003-1664-783X

R. G. Pulido (® https://orcid.org/0000-0002-7107-8054

P. Sepúlveda-Varas @ (ttps://orcid.org/0000-0003-3349-0977

D. Pacheco ๑ https://orcid.org/0000-0002-9307-9197 